\title{
Synthesis and Characterization of a new Cyclohexaphosphate, $\left(\mathrm{C}_{9} \mathrm{H}_{14} \mathrm{~N}\right)_{4}\left(\mathrm{H}_{3} \mathrm{O}\right)_{2}\left(\mathrm{P}_{6} \mathrm{O}_{18}\right)$
}

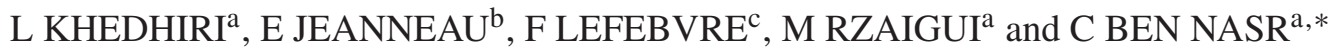 \\ a'Laboratoire de Chimie des Matériaux, Faculté des Sciences de Bizerte, Université de Carthage, \\ 7021 Zarzouna, Tunisie \\ ${ }^{\mathrm{b}}$ Centre de Diffractométrie Henri Longchambon, Université Claude Bernard Lyon 1, Villeurbanne, France \\ ${ }^{\mathrm{c}}$ Laboratoire de Chimie Organométallique de Surface (LCOMS), Ecole Supérieure de Chimie Physique \\ Electronique, 69622 Villeurbanne Cedex, France \\ e-mail: cherif_bennasr@yahoo.fr
}

MS received 8 October 2015; accepted 5 May 2016

\begin{abstract}
The physicochemical properties of a new cyclohexaphosphate, $\left(\mathrm{C}_{9} \mathrm{H}_{14} \mathrm{~N}\right)_{4}\left(\mathrm{H}_{3} \mathrm{O}\right)_{2}\left(\mathrm{P}_{6} \mathrm{O}_{18}\right)$, prepared by an acid-base reaction between cyclohexaphosphoric acid $\mathrm{H}_{6} \mathrm{P}_{6} \mathrm{O}_{18}$ and 2,4,6-trimethylaniline, are discussed on the basis of X-ray crystal structure investigation. The crystal structure determination reveals that the complete cyclohexaphosphate anion, with chair conformation, is generated by crystallographic inversion symmetry. The asymmetric unit consists of two organic cations, one half-anion and one hydronium cation. The atomic arrangement can be described by thick layers built by $\mathrm{P}_{6} \mathrm{O}_{18}$ anions and $\mathrm{H}_{3} \mathrm{O}^{+}$cations parallel to the $(\mathrm{a}, \mathrm{b})$ plane. Each cyclohexaphosphate group is connected to its adjacent neighbors by six hydronium ions through strong O-H...O hydrogen bonds. The protonated amines are located between these successive inorganic layers, in order to balance the negative charge of the inorganic framework by establishing $\mathrm{N}-\mathrm{H}$...O hydrogen bonds with the $\mathrm{O}$ atoms of the $\mathrm{P}_{6} \mathrm{O}_{18}$ anions. The three-dimensional cohesion is assured by different interactions (electrostatic, H-bonds, van der Waals) established between the various molecular components. This compound is also characterized by infrared spectroscopy and solid state MAS-NMR.
\end{abstract}

Keywords. Cyclohexaphosphate; X-ray diffraction; CP-MASNMR; DFT.

\section{Introduction}

Research in organic-inorganic materials has experienced considerable growth in recent years for the purpose of generating materials with desirable properties and functionalities. An important strategy employed in studying such systems has been to take advantage of hydrogen-bond interactions between organic cations and inorganic anions, since they have been recognized as the most powerful force to generate supramolecular networks in one, two and three dimensions. ${ }^{1,2}$ In this context, our aims have been focused on the organic salts of cyclohexaphosphate systems. The literature reports several cyclohexaphosphates of organic and/or inorganic cations. However, cyclohexaphosphates of mixed cations associating the hydronium ion are still relatively very limited. Up to now, only a few examples have been known and structurally characterized. ${ }^{3-5}$ In this work, we report the synthesis and characterization of a new organic hydronium cyclohexaphosphoate, $\left(\mathrm{C}_{9} \mathrm{H}_{14} \mathrm{~N}\right)_{4}\left(\mathrm{H}_{3} \mathrm{O}\right)_{2}\left(\mathrm{P}_{6} \mathrm{O}_{18}\right)$, which has been chosen to elaborate the special hydrogen-bond pattern.

\footnotetext{
*For correspondence
}

\section{Experimental}

\subsection{Chemical preparation}

Crystals of the title compound were prepared by adding dropwise an aqueous solution of cyclohexaphosphoric acid to an ethanolic solution of 2,4,6-dimethylaniline with continuous stirring for few minutes. The obtained solution $(\mathrm{pH}=4)$ was then kept at room temperature until crystallization occurs. After some days of slow evaporation of the mixture, prismatic-shaped crystals with suitable dimensions appeared. The cyclohexaphosphoric acid $\mathrm{H}_{6} \mathrm{P}_{6} \mathrm{O}_{18}$ was produced from $\mathrm{Li}_{6} \mathrm{P}_{6} \mathrm{O}_{18}$. $6 \mathrm{H}_{2} \mathrm{O}$, prepared according to the procedure of Schülke and Kayser, ${ }^{6}$ through an ion-exchange resin in $\mathrm{H}$-state (Amberlite IR 120).

\subsection{X-Ray Single Crystal Structural Analysis}

A suitable crystal was selected and mounted on a Gemini kappa-geometry diffractometer (Agilent Technologies UK Ltd) equipped with an Atlas CCD detector and using Mo radiation $(\lambda=0.71073 \AA$ ). Intensities 
were collected at $100 \mathrm{~K}$ by means of the CrysalisPro software. ${ }^{7}$ Reflection indexing, unit-cell parameters refinement, Lorentz-polarization correction, peak integration and background determination were carried out with the CrysalisPro software. ${ }^{7}$ An analytical absorption correction was applied using the modeled faces of the crystal. ${ }^{8}$ The resulting set of $h k l$ was used for structure solution and refinement.

The structure was solved by direct methods with SIR97 $^{9}$ and the least-square refinement on $\mathrm{F}^{2}$ was achieved with the CRYSTALS software. ${ }^{10}$

All non-hydrogen atoms were refined anisotropically. The hydrogen atoms were all located in a difference map, but those attached to carbon atoms were repositioned geometrically. The $\mathrm{H}$ atoms were initially refined with soft restraints on the bond lengths and angles to regularize their geometry $(\mathrm{C}-\mathrm{H}$ in the range $0.93-0.98$ $\AA$ and $\mathrm{N}-\mathrm{H}$ in the range $0.86-0.89 \AA)$ and $\mathrm{U}_{\text {iso }}(\mathrm{H})$ (in the range 1.2-1.5 times $U_{\text {eq }}$ of the parent atom), after which the positions were refined with riding constraints.
The drawings were made with Diamond. ${ }^{11}$ The details of data collection, refinement and crystallographic data are summarized in table 1 .

\section{$2.3 N M R$ and IR measurements}

The NMR spectra were recorded on a solid-state highresolution Bruker DSX-300 spectrometer operating at $75.49 \mathrm{MHz}$ for ${ }^{13} \mathrm{C}$ and $30.30 \mathrm{MHz}$ for ${ }^{15} \mathrm{~N}$ with a classical $4 \mathrm{~mm}$ probe head allowing spinning rates up to $10 \mathrm{kHz} .{ }^{13} \mathrm{C}$ and ${ }^{15} \mathrm{~N}$ NMR chemical shifts are given relative to tetramethylsilane and neat nitromethane, respectively (precision $0.5 \mathrm{ppm}$ ). The spectra were recorded by use of cross polarization $(\mathrm{CP})$ from protons (contact time $2 \mathrm{~ms}$ ) and magic angle spinning (MAS). Before recording the spectrum, it was checked that there was a sufficient delay between the scans allowing a full relaxation of the protons. The IR spectra were recorded in the range $4000-400 \mathrm{~cm}^{-1}$ with a PerkinElmer FTIR spectrophotometer 1000 using samples

Table 1. Crystal data and experimental parameters used for the intensity data collection. Procedure and final results of the structure determination.

\begin{tabular}{|c|c|}
\hline Empirical formula & $\mathrm{C}_{36} \mathrm{H}_{62} \mathrm{~N}_{4} \mathrm{O}_{20} \mathrm{P}_{6}$ \\
\hline Formula weight $\left[\mathrm{g} \mathrm{mol}^{-1}\right]$ & 1056.74 \\
\hline Crystal colour, habit & colourless, prism \\
\hline Crystal temperature $[\mathrm{K}]$ & 100 \\
\hline Crystal size $\left[\mathrm{mm}^{3}\right]$ & $0.68 \times 0.52 \times 0.21$ \\
\hline Radiation, wavelength $[\AA]$ & $\operatorname{Mo} K \alpha, 0.71073$ \\
\hline Crystal system & monoclinic \\
\hline Space group & $C 2 / c$ \\
\hline \multicolumn{2}{|l|}{ Unit-cell dimensions. } \\
\hline$a[\AA]$ & $17.6878(15)$ \\
\hline$b[\AA]$ & $10.9550(12)$ \\
\hline$c[\AA]$ & $24.687(2)$ \\
\hline$\beta\left[^{\circ}\right]$ & $90.996(8)$ \\
\hline Volume $\left[\AA^{3}\right]$ & $4782.9(8)$ \\
\hline $\mathrm{Z}$ & 4 \\
\hline Density calc. $\left[\mathrm{g} \mathrm{cm}^{-3}\right]$ & 1.467 \\
\hline Reflections for cell determination & 25 \\
\hline$\theta$ range for cell determination $\left[{ }^{\circ}\right]$ & $8-10$ \\
\hline Absorption coefficient $\mu\left[\mathrm{mm}^{-1}\right]$ & 0.31 \\
\hline $\mathrm{F}(000)$ & 2224 \\
\hline$\theta-$ Range for data collection $\left[{ }^{\circ}\right]$ & 3.3 to 29.7 \\
\hline Limiting indices & $-23 \leq \mathrm{h} \leq 22,-14 \leq \mathrm{k} \leq 13,-33 \leq 1 \leq 33$ \\
\hline Reflections collected/unique & $2159 \overline{3} / 58 \overline{7} 6(R$ int $=\overline{0} .05 \overline{8})$ \\
\hline Refinement method & Full-matrix least-squares on $F^{2}$ \\
\hline Data, restrains, parameters $(\mathrm{I}>2 \sigma)$ & $4935,21,326$ \\
\hline Goodness-of-fit on $F^{2}$ & 1.04 \\
\hline Program used & SHELXS $86^{8}$ \\
\hline Determination & CRYSTALS $^{9}$ \\
\hline $\mathrm{R}$ indices (all data, on $F^{2}$ ) & $\mathrm{R}_{1}=0.055, \mathrm{wR}_{2}=0.121$ \\
\hline$\delta \rho(\min , \max )\left[\mathrm{e} \AA^{-3}\right]$ & -0.79 and 0.93 \\
\hline Drawing made with & Diamond $^{10}$ \\
\hline
\end{tabular}


dispersed in spectroscopically pure $\mathrm{KBr}$ pressed into a pellet.

\section{Results and Discussion}

\subsection{Structure description}

The title compound exhibits a layered structure. All non-hydrogen atoms occupy general positions in the unit cell, except the atoms, $\mathrm{O} 1$ and $\mathrm{O} 10$ which are located on special positions. The experimental parameters used for data collection and determination of the structure are listed in table 1. Interatomic distances, bond angles and the hydrogen bonds are given in tables 2 and 3.

The asymmetric unit of the organic cyclohexaphosphates includes one-half of the $\mathrm{P}_{6} \mathrm{O}_{18}$ ring lying on an inversion center, two 2,4,6-trimethylanilinium cations and one hydronium cation (figure 1). In the atomic arrangement, each cyclohexaphosphate anion is linked to six hydronium cations through strong O-H...O hydrogen bonds to form 2-D inorganic layers separated by a distance of 12.34(2) $\AA$, which develop parallel to the (a, b) plane (figure 2). The organic cations are located between these layers at $\mathrm{z}=1 / 4$ and $\mathrm{z}=3 / 4$ and connect them via $\mathrm{N}-\mathrm{H}$...O hydrogen bonds (figure 3 ). The
Table 3. Hydrogen-bond geometry $\left(\AA,^{\circ}\right)$.

\begin{tabular}{|c|c|c|c|c|}
\hline$D-H \cdots A$ & $D-H$ & $H \cdots A$ & $D \cdots A$ & $D-H \cdots A$ \\
\hline $\mathrm{O} 11-\mathrm{H} 29 \ldots \mathrm{O} 6$ & 0.85 & 1.85 & $2.691(4)$ & $170(4)$ \\
\hline $\mathrm{O} 11-\mathrm{H} 30 \cdots \mathrm{O} 2^{\mathrm{ii}}$ & 0.83 & 1.71 & $2.527(4)$ & $166(4)$ \\
\hline $\mathrm{O} 11-\mathrm{H} 31 \cdots \mathrm{O} 8^{\mathrm{iii}}$ & 0.83 & 1.59 & $2.423(4)$ & $176(4)$ \\
\hline $\mathrm{N} 1-\mathrm{H} 2 \cdots \mathrm{O} 2^{\mathrm{ii}}$ & 0.89 & 2.04 & $2.778(4)$ & $139(2)$ \\
\hline $\mathrm{N} 1-\mathrm{H} 1 \cdots \mathrm{O} 5^{\mathrm{ii}}$ & 0.88 & 1.91 & $2.758(4)$ & $161(2)$ \\
\hline $\mathrm{N} 1-\mathrm{H} 3 \cdots \mathrm{O} 6$ & 0.90 & 1.89 & $2.772(4)$ & $167(3)$ \\
\hline $\mathrm{N} 2-\mathrm{H} 15 \cdots \mathrm{O} 5^{\mathrm{i}}$ & 0.90 & 1.86 & $2.746(4)$ & $169(2)$ \\
\hline $\mathrm{N} 2-\mathrm{H} 16 \cdots \mathrm{O} 9$ & 0.91 & 1.85 & $2.755(4)$ & $177(2)$ \\
\hline $\mathrm{N} 2-\mathrm{H} 17 \cdots \mathrm{O} 3$ & 0.90 & 2.01 & $2.776(4)$ & $142(2)$ \\
\hline
\end{tabular}

Symmetry codes: (i) $-x+1, y,-z+1 / 2$; (ii) $-x+3 / 2$, $y-1 / 2,-z+1 / 2$; (iii) $-x+3 / 2, y+1 / 2,-z+1 / 2$.

same phenomenon has been observed for $\left(\mathrm{C}_{10} \mathrm{H}_{13} \mathrm{NH}_{3}\right)_{4}$. $\left(\mathrm{H}_{3} \mathrm{O}\right)_{2} \cdot \mathrm{P}_{6} \mathrm{O}_{18} \cdot 3 \mathrm{H}_{2} \mathrm{O}$ and $\left(\mathrm{C}_{7} \mathrm{H}_{10} \mathrm{~N}\right)_{4} \cdot\left(\mathrm{H}_{3} \mathrm{O}\right)_{2} \cdot \mathrm{P}_{6} \mathrm{O}_{18} \cdot{ }^{4,5}$ The $\mathrm{N}(2) \mathrm{H}_{3}$ groups produce the internal $\mathrm{P}_{6} \mathrm{O}_{18}$ ring cohesion through hydrogen bonds involving external oxygen atoms of each $\mathrm{PO}_{4}$ tetrahedron. The other $\mathrm{N}(1) \mathrm{H}_{3}$ groups, link two different rings and so contribute to the interlayer cohesion of this compound (figure 3, table 3).

It should be pointed out that, in addition to the extensive network of $\mathrm{N}-\mathrm{H} . . . \mathrm{O}$ and $\mathrm{O}-\mathrm{H}$...O hydrogen-bonds which link the components of the structure into a threedimensional network, the structure is further stabilized with electrostatic and van der Waals interactions.

Table 2. Main interatomic distances $(\AA)$ and bond angles $\left(^{\circ}\right)$ in the inorganic groups of $\left(\mathrm{C}_{9} \mathrm{H}_{14} \mathrm{~N}\right)_{4}\left(\mathrm{H}_{3} \mathrm{O}\right)_{2}\left(\mathrm{P}_{6} \mathrm{O}_{18}\right)$.

\begin{tabular}{lcccc}
\hline$P(1) O_{4}$ & tetrahedron & & & \\
$\mathrm{P} 1$ & $\mathrm{O} 1$ & $\mathrm{O} 2$ & $\mathrm{O} 3$ & $\mathrm{O} 4$ \\
$\mathrm{O} 1$ & $1.6025(13)$ & $2.506(2)$ & $2.541(2)$ & $2.451(2)$ \\
$\mathrm{O} 2$ & $107.73(11)$ & $1.499(2)$ & $2.568(2)$ & $2.541(2)$ \\
$\mathrm{O} 3$ & $111.20(9)$ & $119.40(12)$ & $1.475(2)$ & $2.504(2)$ \\
$\mathrm{O} 4$ & $99.23(11)$ & $109.28(11)$ & $108.11(12)$ & $1.616(2)$ \\
$\mathrm{P}(2) \mathrm{O}_{4}$ & tetrahedron & & & \\
$\mathrm{P} 2$ & $\mathrm{O} 4$ & $\mathrm{O} 5$ & $\mathrm{O} 6$ & $\mathrm{O} 7$ \\
$\mathrm{O} 4$ & $1.594(2)$ & $2.549(2)$ & $2.488(2)$ & $2.505(2)$ \\
$\mathrm{O} 5$ & $111.20(11)$ & $1.4944(19)$ & $2.533(2)$ & $2.471(2)$ \\
$\mathrm{O} 6$ & $107.93(11)$ & $116.67(11)$ & $1.482(2)$ & $2.541(2)$ \\
$\mathrm{O} 7$ & $103.29(10)$ & $105.92(11)$ & $111.02(11)$ & $1.600(2)$ \\
$P(3) O_{4}$ & tetrahedron & & & \\
$\mathrm{P} 3$ & $\mathrm{O} 7$ & $\mathrm{O} 8$ & $\mathrm{O} 9$ & $\mathrm{O} 10$ \\
$\mathrm{O} 7$ & $1.6110(19)$ & $2.498(2)$ & $2.549(2)$ & $2.455(2)$ \\
$\mathrm{O} 8$ & $107.25(11)$ & $1.491(2)$ & $2.559(2)$ & $2.468(2)$ \\
$\mathrm{O} 9$ & $111.27(11)$ & $119.29(12)$ & $1.475(2)$ & $2.534(2)$ \\
$\mathrm{O} 10$ & $99.90(10)$ & $106.11(12)$ & $111.15(9)$ & $1.5958(12)$ \\
& & &
\end{tabular}

Symmetry code: (i) $-x+1, y,-z+1 / 2$.

$\mathrm{P} 1-\mathrm{P} 2=2.926(5) \mathrm{P} 2-\mathrm{O} 4-\mathrm{P} 1=131.48(0) \mathrm{P} 1-\mathrm{P} 2-\mathrm{P} 3=100.45(0)$

$\mathrm{P} 2-\mathrm{P} 3=2.937(3) \mathrm{P} 1-\mathrm{O} 1-\mathrm{P} 1^{\mathrm{i}}=130.24(1) \mathrm{P} 2-\mathrm{P} 3-\mathrm{P} 3^{\mathrm{i}}=105.54(0)$

$\mathrm{P} 1-\mathrm{P} 1^{\mathrm{i}}=2.908(12) \mathrm{P}^{\mathrm{i}}-\mathrm{O} 7^{\mathrm{i}}-\mathrm{P} 3^{\mathrm{i}}=132.26(0)$

$\mathrm{P} 1^{\mathrm{i}}-\mathrm{P} 1-\mathrm{P} 2=97.07(0)$

$\mathrm{P} 3-\mathrm{P} 3^{\mathrm{i}}=2.960(11) \mathrm{P}^{\mathrm{i}}-\mathrm{O} 10-\mathrm{P} 3=136.07(1)$. 


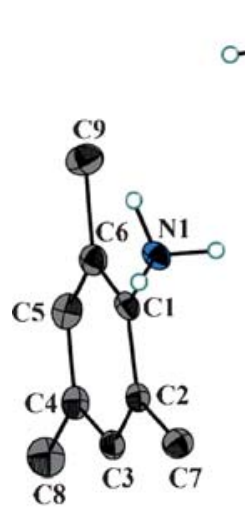

$-\oint^{011}$



Figure 1. An ORTEP view of $\left(\mathrm{C}_{9} \mathrm{H}_{14} \mathrm{~N}\right)_{4}\left(\mathrm{H}_{3} \mathrm{O}\right)_{2}\left(\mathrm{P}_{6} \mathrm{O}_{18}\right)$ with the atom-labeling. Displacement ellipsoids are drawn at $40 \%$ probability. $\mathrm{H}$-atoms are represented as small arbitrary radii. Symmetry code: (i) x, y, z.

Inside these layers, the phosphoric ring displays a chair conformation with geometrical characteristics that show no significant difference in deviation from those observed in other cyclohexaphosphates having the same internal symmetry $-1 .^{12-17}$ Averages of the P-O$\mathrm{P}$ and P-P-P angles are $132.2^{\circ}$ and $101.0^{\circ}$, respectively. Nevertheless, this distortion is comparatively far from

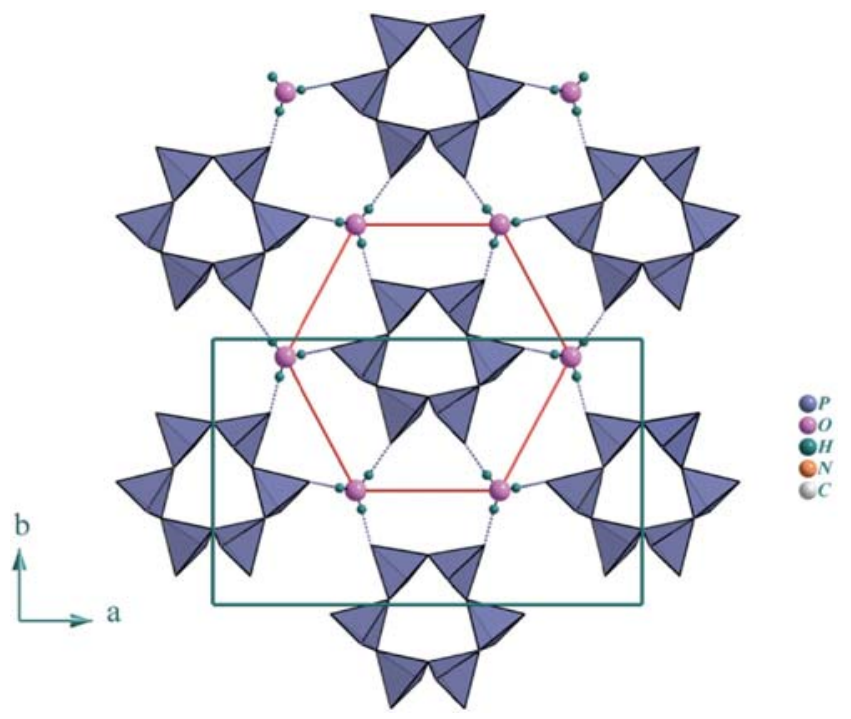

Figure 2. Projection along the $\mathrm{c}$ axis, of an inorganic layer in the structure of $\left(\mathrm{C}_{9} \mathrm{H}_{14} \mathrm{~N}\right)_{4}\left(\mathrm{H}_{3} \mathrm{O}\right)_{2}\left(\mathrm{P}_{6} \mathrm{O}_{18}\right)$ showing the geometry around the $\mathrm{P}_{6} \mathrm{O}_{18}$ anion.



Figure 3. The three-dimensional network of $\left(\mathrm{C}_{9} \mathrm{H}_{14} \mathrm{~N}\right)_{4}$ $\left(\mathrm{H}_{3} \mathrm{O}\right)_{2}\left(\mathrm{P}_{6} \mathrm{O}_{18}\right)$, projected along the b-axis.

what is reported either in $\mathrm{Cs}_{6} \mathrm{P}_{6} \mathrm{O}_{18} \cdot 6 \mathrm{H}_{2} \mathrm{O}^{18}$ or in higher phosphoric rings as in (gua) ${ }_{10} \mathrm{P}_{10} \mathrm{O}_{30} \cdot 4 \mathrm{H}_{2} \mathrm{O},{ }^{19}$ which shows the greatest distortion for the P-P-P angles ranging from 99.5 to $145.9^{\circ}$. This wide range of values can probably explain the pronounced distortion observed for the big rings compared with their smaller ring analogues.

The calculated average values of the distortion indices corresponding to the different angles and distances in the $\mathrm{PO}_{4}$ tetrahedra [DI $(\mathrm{OPO})=0.038$; DI $(\mathrm{PO})=0.040$; and DI $(\mathrm{OO})=0.011]($ table 4$)$, show a pronounced distortion of the PO distances and OPO angles if compared to $\mathrm{OO}$ distances. So, the $\mathrm{PO}_{4}$ group can be considered as a rigid regular arrangement of oxygen atoms, with the phosphorus atom slightly displaced from the gravity centre $(\delta \mathrm{P} 1=0.147, \delta \mathrm{P} 2=0.106, \delta \mathrm{P} 3$ $=0.145$ ).

The organic entities lie across a crystallographic inversion centre and hence the asymmetric unit contains two cations. The interatomic bond lengths $(\mathrm{C}-\mathrm{C}, \mathrm{N}-\mathrm{C})$ and angles (C-C-C, C-N-C) (table 5) are close to those reported in the literature for similar compounds. ${ }^{20-23}$ The aromatic rings are planar with an r.m.s. deviation of $0.0047 \AA$ and form a dihedral angle of $14.42^{\circ}$.

A comparison of the title compound (I) to bis(oxonium) tetrakis(o-toluidinium) cyclohexaphosphate (II), to bis(oxonium) tetrakis(2,6-diethylphenylammonium) (III) cyclohexaphosphate trihydrate (IV) and to bis(oxonium) bis[1-(2,3-dimethylphenyl)piperazine-1,4-diium] cyclohexaphosphate dihydrate (IV) shows some similarities between these structures. In fact these structures have a layer organization where the organic and the inorganic 
Table 4. Interatomic PO distances $(\AA)$, OPO angles (degrees) tetrahedral distortion indexes ID(PO), ID(OPO) and ID $(\mathrm{OO})$ of the cyclohexaphosphate $\left(\mathrm{C}_{9} \mathrm{H}_{14} \mathrm{~N}\right)_{4}$ $\left(\mathrm{H}_{3} \mathrm{O}\right)_{2}\left(\mathrm{P}_{6} \mathrm{O}_{18}\right)$.

\begin{tabular}{lcccccc}
\hline Tetrahedron & $\mathrm{P}-\mathrm{O}_{\mathrm{m}}$ & ID $(\mathrm{P}-\mathrm{O})$ & $(\mathrm{O}-\mathrm{P}-\mathrm{O})_{\mathrm{m}}$ & $\mathrm{ID}(\mathrm{OPO})$ & $\mathrm{O}-\mathrm{O}_{\mathrm{m}}$ & ID $(\mathrm{O}-\mathrm{O})$ \\
\hline $\mathrm{P}_{1}\left(\mathrm{O}_{4}\right)$ & 1.540 & 0.045 & 109.16 & 0.038 & 2.534 & 0.007 \\
$\mathrm{P}_{2}\left(\mathrm{O}_{4}\right)$ & 1.543 & 0.035 & 109.34 & 0.033 & 2.515 & 0.011 \\
$\mathrm{P}_{3}\left(\mathrm{O}_{4}\right)$ & 1.543 & 0.039 & 109.16 & 0.043 & 2.511 & 0.015 \\
\hline
\end{tabular}

species are alternated. In addition, the anionic networks contain centrosymmetric cyclohexaphosphate anions where the six $\mathrm{P}$ atoms of each $\mathrm{P}_{6} \mathrm{O}_{18}^{6-}$ anion form a chair conformation. Similarly as in (I), the $\mathrm{H}_{3} \mathrm{O}^{+}$ions in (II), (III) and (IV) exhibit a pyramidal configuration.

Comparing the structure of compound (IV) with that of compounds I, II and III, we found that the connection mode of $\mathrm{P}_{6} \mathrm{O}_{18}^{6-}$ anions are different. The difference in connection mode in these structures induces different rearrangement atomic type. Thus, in the structure (IV), a protonated water molecule bridges the $\mathrm{P}_{6} \mathrm{O}_{18}^{6-}$ anions via $\mathrm{O}-\mathrm{H}$...O hydrogen bonds. So the centrosymmetric hydrogen-bonded rings formed by four oxonium cations and four phosphate anions which can be described by an $R_{4}^{8}(36)$ graph-set motif (figure 4 ). The ring motifs are connected by hydrogen bonds into inorganic layers perpendicular to [100]. In structures (I) (II) and (III), each cyclohexaphosphate group is connected to its adjacent neighbors by six oxonium ions through strong $\mathrm{O}-\mathrm{H} \cdots \mathrm{O}$ hydrogen bonds (figure 2).

In spite of these differences, the geometrical parameters of cyclohexaphosphoric groups have comparable values in the four compounds and are similar to those observed in other cyclohexaphosphates. In addition, the organic molecules exhibit regular spatial configurations with usual distances $\mathrm{C}-\mathrm{C}, \mathrm{C}-\mathrm{N}$, and angles $\mathrm{C}-\mathrm{C}-\mathrm{C}, \mathrm{C}-$ $\mathrm{C}-\mathrm{N}$. Added to that, all these structures are built up by a large number of similar hydrogen bonds formed between organic groups, cyclohexaphosphoric anions and oxonium ions.

Table 5. Selected bond lengths $(\AA)$ and bond angles $\left(^{\circ}\right)$ in the organic groups of $\left(\mathrm{C}_{9} \mathrm{H}_{14} \mathrm{~N}\right)_{4}\left(\mathrm{H}_{3} \mathrm{O}\right)_{2}\left(\mathrm{P}_{6} \mathrm{O}_{18}\right)$.

$\left[\mathrm{C}_{9} \mathrm{H}_{14} \mathrm{~N}(1)\right]$ group
$\mathrm{N} 1-\mathrm{C} 11.467(3)$
$\mathrm{C} 1-\mathrm{C} 21.395(4)$
$\mathrm{C} 1-\mathrm{C} 61.396(4)$
$\mathrm{C} 2-\mathrm{C} 31.389(4)$
$\mathrm{C} 2-\mathrm{C} 71.505(4)$
$\mathrm{C} 3-\mathrm{C} 41.398(4)$
$\mathrm{C} 4-\mathrm{C} 51.393(4)$
$\mathrm{C} 4-\mathrm{C} 81.510(4)$
$\mathrm{C} 5-\mathrm{C} 61.394(4)$
$\mathrm{C} 6-\mathrm{C} 91.515(4)$

$\left[\mathrm{C}_{9} \mathrm{H}_{14} \mathrm{~N}(2)\right]$ group

$\begin{array}{ll}\mathrm{N} 2-\mathrm{C} 10 & 1.470(3) \\ \mathrm{C} 10-\mathrm{C} 11 & 1.401(4) \\ \mathrm{C} 10-\mathrm{C} 15 & 1.398(4) \\ \mathrm{C} 11-\mathrm{C} 12 & 1.391(4) \\ \mathrm{C} 11-\mathrm{C} 16 & 1.515(4) \\ \mathrm{C} 12-\mathrm{C} 13 & 1.400(4) \\ \mathrm{C} 13-\mathrm{C} 14 & 1.393(4) \\ \mathrm{C} 13-\mathrm{C} 17 & 1.504(4) \\ \mathrm{C} 14-\mathrm{C} 15 & 1.395(4) \\ \mathrm{C} 15-\mathrm{C} 18 & 1.509(4)\end{array}$

$\begin{array}{ll}\mathrm{N} 1-\mathrm{C} 1-\mathrm{C} 2 & 117.8(2) \\ \mathrm{N} 1-\mathrm{C} 1-\mathrm{C} 6 & 119.0(2) \\ \mathrm{C} 2-\mathrm{C} 1-\mathrm{C} 6 & 123.1(3) \\ \mathrm{C} 1-\mathrm{C} 2-\mathrm{C} 3 & 117.8(3) \\ \mathrm{C} 1-\mathrm{C} 2-\mathrm{C} 7 & 120.9(2) \\ \mathrm{C} 3-\mathrm{C} 2-\mathrm{C} 7 & 121.3(2) \\ \mathrm{C} 2-\mathrm{C} 3-\mathrm{C} 4 & 121.6(3) \\ \mathrm{C} 3-\mathrm{C} 4-\mathrm{C} 5 & 118.1(3) \\ \mathrm{C} 3-\mathrm{C} 4-\mathrm{C} 8 & 119.9(3) \\ \mathrm{C} 5-\mathrm{C} 4-\mathrm{C} 8 & 122.0(3) \\ \mathrm{C} 4-\mathrm{C} 5-\mathrm{C} 6 & 122.7(3) \\ \mathrm{C} 1-\mathrm{C} 6-\mathrm{C} 5 & 116.6(3) \\ \mathrm{C} 1-\mathrm{C} 6-\mathrm{C} 9 & 121.8(3) \\ \mathrm{C} 5-\mathrm{C} 6-\mathrm{C} 9 & 121.7(3)\end{array}$

$\mathrm{N} 2-\mathrm{C} 10-\mathrm{C} 15$ 


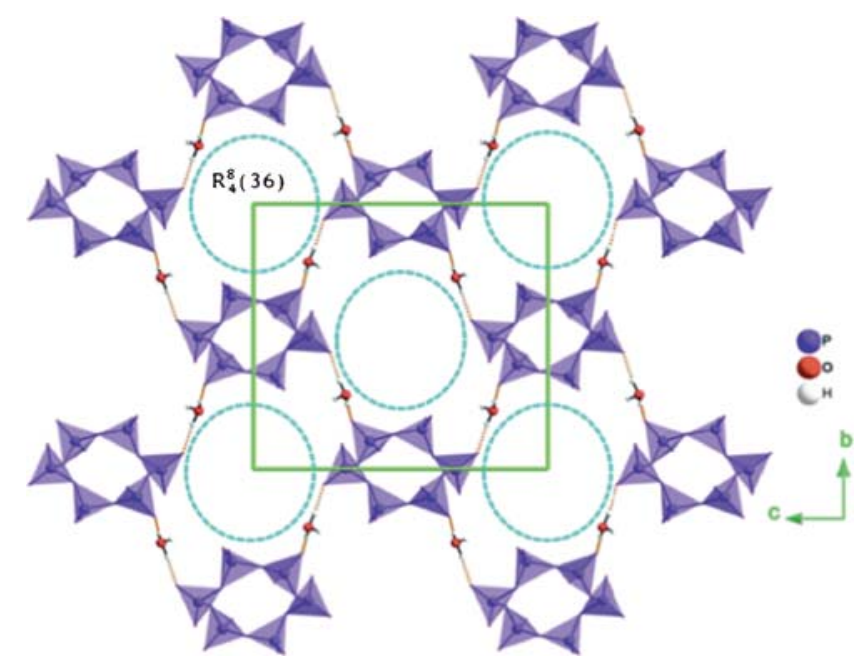

Figure 4. Projection along the a axis, of an inorganic layer in the structure of (IV). The dashed circles highlight the $\mathrm{R}_{4}^{8}(36)$ centrosymmetric motifs.

\subsection{NMR results}

The aliphatic carbon resonance domain of the ${ }^{13} \mathrm{C} \mathrm{CP}$ MAS NMR spectrum of $\left(\mathrm{C}_{9} \mathrm{H}_{14} \mathrm{~N}\right)_{4}\left(\mathrm{H}_{3} \mathrm{O}\right)_{2}\left(\mathrm{P}_{6} \mathrm{O}_{18}\right)$ is shown in figure 5. It exhibits five sharp resonances between 15.2 and $19.3 \mathrm{ppm}$, one of the peaks having about double the integrated intensity of the other four. The spectrum can thus be interpreted as featuring six resonances, with two of them in close proximity with a substantial overlap. This is in agreement with two organic molecules being present in the asymmetric unit cell as revealed by the X-ray structure determination. In the aromatic carbon resonance domain, ranging from 123.9 to $139.3 \mathrm{ppm}$, the spectrum shows at least nine peaks with different intensities and line widths (figure 6). The failure to resolve all the peaks can be attributed to the overlapping of resonance signals. This signal number more than six confirms also the presence of two organic molecules in the asymmetric unit cell.

The ${ }^{15} \mathrm{~N}$ CP-MAS NMR spectrum of the title compound (figure 7) is also in good agreement with the $\mathrm{X}$ ray structure. Indeed, it exhibits two well-defined resonances at -358.4 and $-359.8 \mathrm{ppm}$ corresponding to the two crystallographically independent nitrogen atoms, in agreement with two organic cations in the unit cell.

Theoretical calculations were undertaken in order to assign the NMR resonances to the different crystallographically unequivalent atoms of the unit cell. The atoms are labeled as depicted below:<smiles>Cc1cc(C)c([NH3+])c(C)c1</smiles>

Three different calculations were made on the organic cation and in all cases the theoretical chemical shifts were substracted from those of the reference (tetramethylsilane for carbon with $\delta_{\exp }=0 \mathrm{ppm}$ and glycine for nitrogen with $\delta_{\exp }=-347.2 \mathrm{ppm}$ ) calculated at the same level of theory:

(1) Calculation of the NMR chemical shifts (with the GIAO method) by using the positions of atoms obtained by X-ray diffraction;

(2) Optimization of the positions of the protons in the above molecule and calculation of the NMR

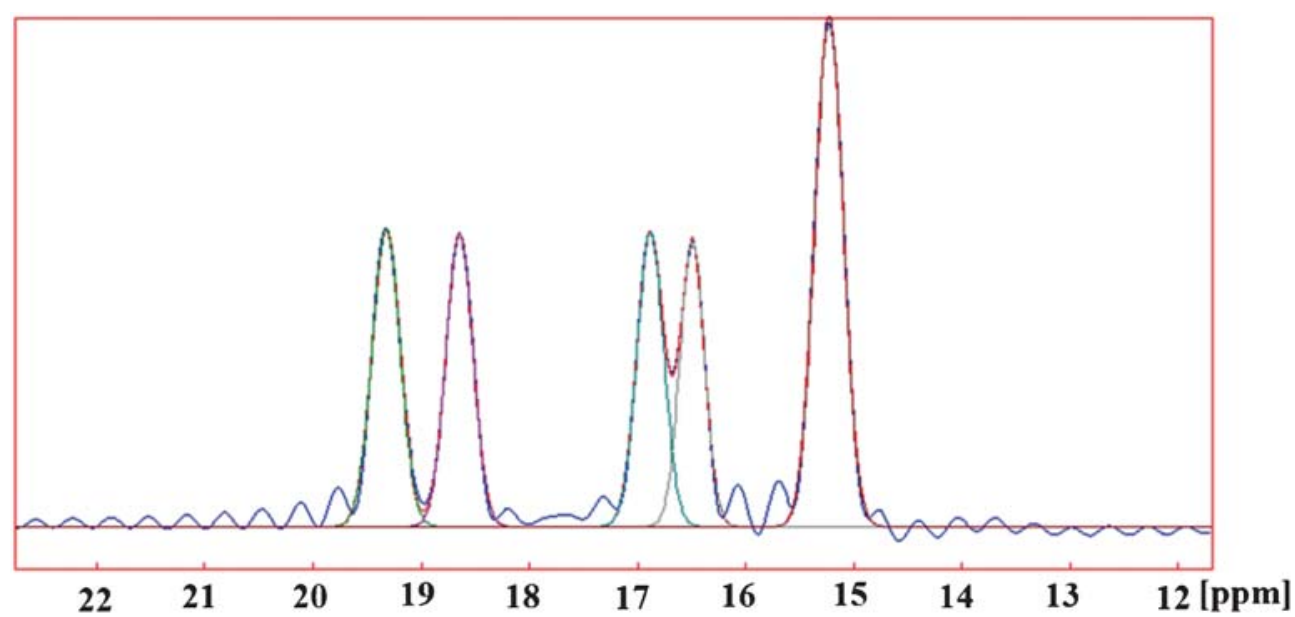

Figure 5. Simulated and experimental signals of the aliphatic carbon resonance domain of the ${ }^{13} \mathrm{C}$ CP-MAS NMR spectrum of $\left(\mathrm{C}_{9} \mathrm{H}_{14} \mathrm{~N}\right)_{4}\left(\mathrm{H}_{3} \mathrm{O}\right)_{2}\left(\mathrm{P}_{6} \mathrm{O}_{18}\right)$. 


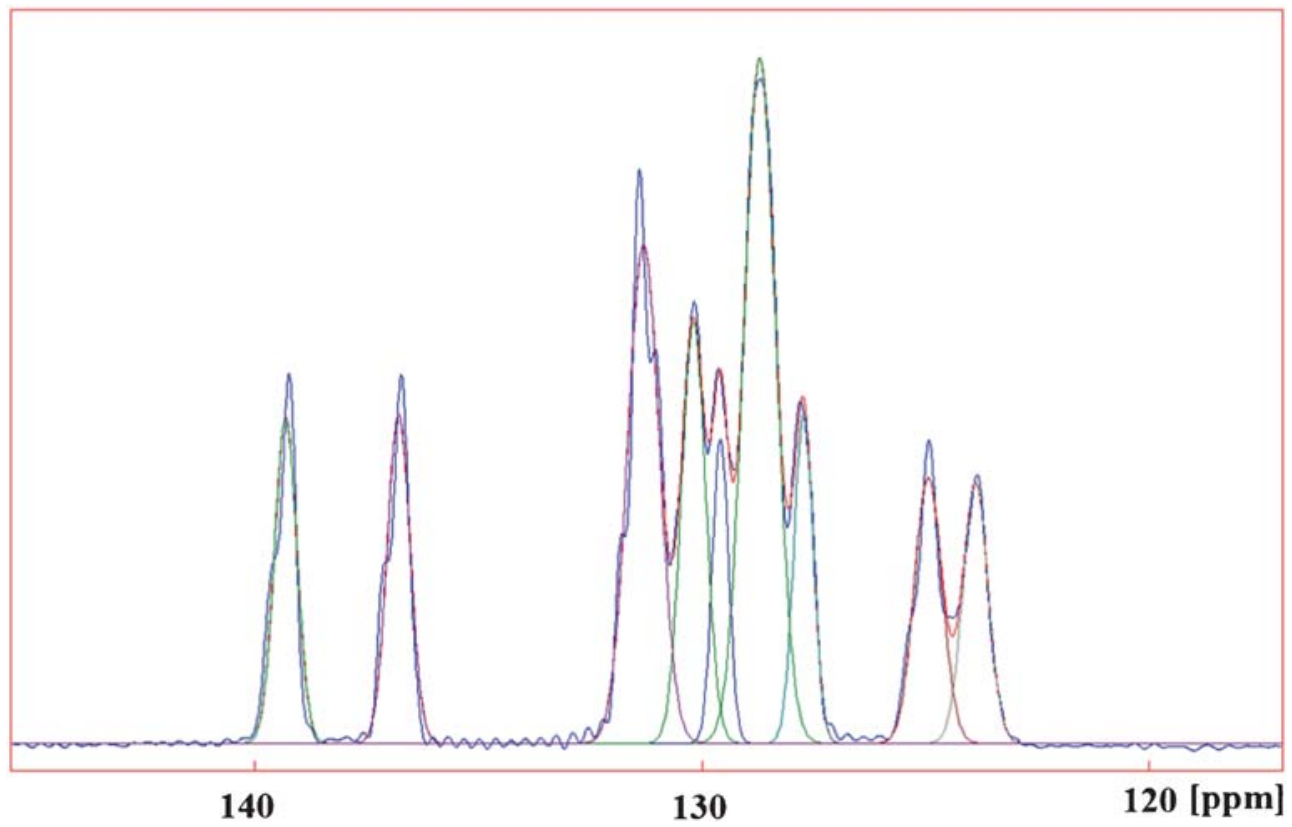

Figure 6. Simulated and experimental signals of the aromatic carbon resonance domain of the ${ }^{13} \mathrm{C}$ CP-MAS NMR spectrum of $\left(\mathrm{C}_{9} \mathrm{H}_{14} \mathrm{~N}\right)_{4}\left(\mathrm{H}_{3} \mathrm{O}\right)_{2}\left(\mathrm{P}_{6} \mathrm{O}_{18}\right)$.

chemical shifts in this semi-optimized geometry. Indeed, X-ray diffraction leads always to underestimate $\mathrm{X}-\mathrm{H}$ bond lengths, due to the fact that it is sensitive to the electronic cloud and does not see the nuclei;

(3) Full optimization of all atoms and calculation of NMR chemical shifts. This calculation, compared to the above ones can give indications on the steric hindrance around the organic cation and on the positions where it is the strongest.
The results are listed on table 6 . Clearly, there is a very good agreement between the experimental and the theoretical values calculated after optimization of the position of the protons, allowing unambiguously the attribution of the different NMR signals.

\subsection{IR spectroscopy}

FTIR spectroscopy was used to verify the functional groups present in the crystal and to investigate their



Figure 7. ${ }^{15} \mathrm{~N}$ CP-MAS NMR spectrum of $\left(\mathrm{C}_{9} \mathrm{H}_{14} \mathrm{~N}\right)_{4}\left(\mathrm{H}_{3} \mathrm{O}\right)_{2}\left(\mathrm{P}_{6} \mathrm{O}_{18}\right)$. 
Table 6. Chemical shift values of the carbon and nitrogen atoms in the title compound.

\begin{tabular}{|c|c|c|c|c|c|c|}
\hline \multirow{2}{*}{$\frac{\text { Atom }}{\mathrm{C} 1}$} & \multicolumn{2}{|c|}{$\mathrm{X}$-rays } & \multirow{2}{*}{$\begin{array}{c}\begin{array}{c}\text { Full } \\
\text { optimization }\end{array} \\
128.8\end{array}$} & \multicolumn{2}{|c|}{$\begin{array}{l}\text { Optimisation } \\
\text { of hydrogens }\end{array}$} & \multirow{2}{*}{$\begin{array}{c}\text { Experiment } \\
123.9 \\
124.9\end{array}$} \\
\hline & 123.2 & 122.0 & & 126.2 & 125.2 & \\
\hline $\mathrm{C} 2$ & 139.1 & 137.2 & 136.8 & 137.9 & 136.4 & $128-131$ \\
\hline & 137.8 & 138.4 & & 137.2 & 137.1 & \\
\hline C3 & 131.5 & 130.6 & 139.4 & $\begin{array}{l}138.4 \\
138.7\end{array}$ & $\begin{array}{l}137.4 \\
1390\end{array}$ & \\
\hline $\mathrm{C} 4$ & $\begin{array}{l}132.5 \\
1597\end{array}$ & $\begin{array}{l}132.9 \\
1591\end{array}$ & & $\begin{array}{l}138.7 \\
158.4\end{array}$ & $\begin{array}{l}139.0 \\
1580\end{array}$ & \\
\hline $\mathrm{CH}_{3}$ ortho & $\begin{array}{l}-5.8 \\
-2.8\end{array}$ & $\begin{array}{l}1.1 \\
-2.7 \\
-2.0\end{array}$ & 18.2 & $\begin{array}{l}18.0 \\
18.9\end{array}$ & $\begin{array}{r}15.0 \\
18.6 \\
17.9\end{array}$ & 15.2 to 16.9 \\
\hline $\begin{array}{l}\mathrm{CH}_{3} \text { para } \\
\mathrm{N}\end{array}$ & $\begin{array}{c}0.7 \\
-348.3\end{array}$ & $\begin{array}{c}0.9 \\
-351.6\end{array}$ & $\begin{array}{r}23.9 \\
-313.7\end{array}$ & $\begin{array}{r}23.6 \\
-314.6\end{array}$ & $\begin{array}{r}23.9 \\
-314.1\end{array}$ & $\begin{array}{c}18.6 \text { and } 19.3 \\
-358.4 \text { and }-359.8\end{array}$ \\
\hline
\end{tabular}

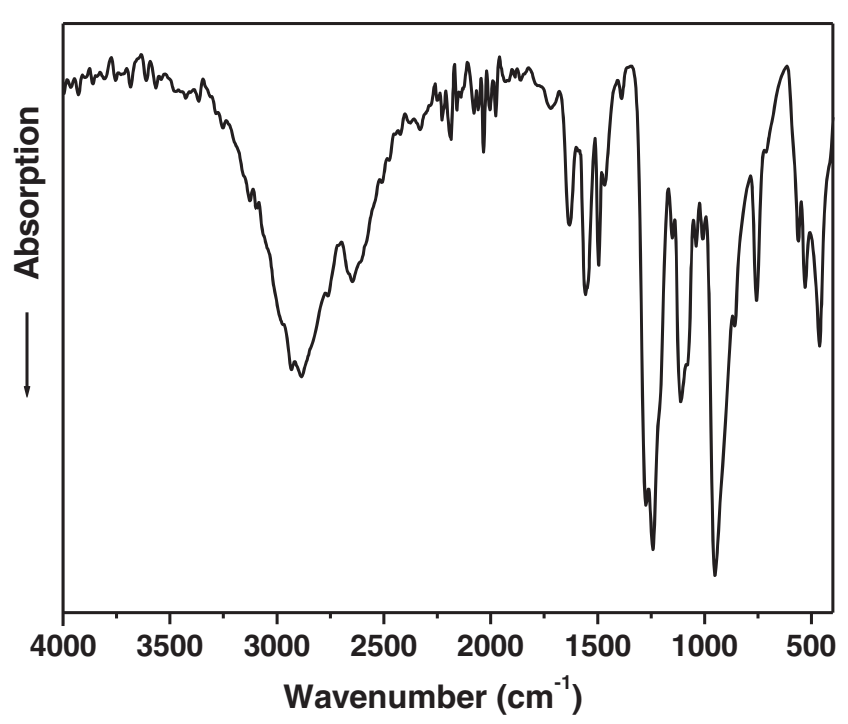

Figure 8. Infrared spectrum of $\left(\mathrm{C}_{9} \mathrm{H}_{14} \mathrm{~N}\right)_{4}\left(\mathrm{H}_{3} \mathrm{O}\right)_{2}\left(\mathrm{P}_{6} \mathrm{O}_{18}\right)$.

vibrational behavior in the solid state. The IR spectrum of $\left(\mathrm{C}_{9} \mathrm{H}_{14} \mathrm{~N}\right)_{4} \cdot\left(\mathrm{H}_{3} \mathrm{O}\right)_{2} .\left(\mathrm{P}_{6} \mathrm{O}_{18}\right)$ is shown in figure 8 . The characteristic vibrational modes of this compound can be compared to those of similar materials containing cyclohexaphosphates. ${ }^{24}$ The bands in the high-frequency region, between 3400 and $2500 \mathrm{~cm}^{-1}$, correspond to the stretching vibrations of the $\mathrm{N}-\mathrm{H}, \mathrm{C}-\mathrm{H}$ and $\mathrm{O}-\mathrm{H}$ groups interconnected by a system of hydrogen bonds in the crystal. ${ }^{25}$ The band at $1642 \mathrm{~cm}^{-1}$ corresponds to $\delta(\mathrm{O}-\mathrm{H})$ and $\delta(\mathrm{N}-\mathrm{H})$ deformation vibrations. The two bands at 1556 and $1495 \mathrm{~cm}^{-1}$ are assigned to $v(\mathrm{C}=\mathrm{C})_{\mathrm{Ar}}$ stretching vibrations. ${ }^{26,27}$ The strong bands observed in the ranges 1350-1180, 1180-1060, 1060-960, and 850-660 $\mathrm{cm}^{-1}$ can be assigned to stretching vibrations $v_{\text {as }}(\mathrm{OPO})$, $v_{\mathrm{s}}(\mathrm{OPO}), v_{\mathrm{as}}(\mathrm{POP})$, and $v_{\mathrm{s}}(\mathrm{POP})$, respectively. ${ }^{28,29} \mathrm{We}$ note that the supplementary frequency in the $v_{\mathrm{s}}(\mathrm{OPO})$ domain can be assigned to the stretching $v(\mathrm{C}-\mathrm{C})$ and $\nu(\mathrm{C}-\mathrm{N}), \delta(\mathrm{C}-\mathrm{H})$ and $\gamma(\mathrm{C}-\mathrm{H})$ vibrations. ${ }^{30}$ Frequencies below $660 \mathrm{~cm}^{-1}$ can be assigned to bending, translation and rotation of the $\mathrm{P}_{6} \mathrm{O}_{18}$ ring anion.

\section{Conclusions}

A new cyclohexaphosphate, $\left(\mathrm{C}_{9} \mathrm{H}_{14} \mathrm{~N}\right)_{4}\left(\mathrm{H}_{3} \mathrm{O}\right)_{2}\left(\mathrm{P}_{6} \mathrm{O}_{18}\right)$, has been prepared at room temperature and characterized by physicochemical methods. In the atomic arrangement, each cyclohexaphosphate anion is surrounded by six hydronium cations to build inorganic layers perpendicular to the c-axis. The organic cations are anchored between these layers and connect them via hydrogen bonds to form an infinite three-dimensional network. The structure cohesion is ensured by $\mathrm{N}-\mathrm{H}$...O and $\mathrm{O}-\mathrm{H} . . . \mathrm{O}$ hydrogen bonds. The number of ${ }^{13} \mathrm{C}$ and ${ }^{15} \mathrm{~N}$ CP-MAS NMR lines is in full agreement with the crystallographic data. DFT calculations allow the attribution of the experimental NMR lines. The vibrational absorption bands were identified by infrared spectroscopy.

\section{Supplementary Information (SI)}

Crystallographic data for the structural analysis have been deposited at the Cambridge Crystallographic Data Centre, CCDC No 1059678. These data can be obtained free of charge via http://www.ccdc.cam.ac.uk/conts/ retrieving.html, or from the CCDC, 12 Union Road, Cambridge, CB2 1EZ, UK: fax: (+44) 01223-336033; e-mail: deposit@ccdc.cam.ac. Crystal data and geometry parameters are available in Supplementary Information at www.ias.ac.in/chemsci.

\section{References}

1. Ozin G A 1992 Adv. Mater. 4612

2. Teraski O, Barry J C and Thomas J M 1987 Nature (London) 33058

3. Ameur I, Abid S, Al-Deyab S S and Rzaigui M 2013 Acta Cryst. E 69 o1145

4. Marouani H, Rzaigui M and Al-Deyab S S 2010 Acta Cryst. E 66 o 702 
5. Amri O, Abid S and Rzaigui M 2008 Phosphorus, Sulfur Silicon Relat. Elem. 1831984

6. Schülke U and Kayser R 1985 Z. Anorg. Allg. Chem. 531 167

7. CrysAlisPro, Agilent Technologies, Version 1.171.34.49 (release 20-01-2011 CrysAlis171.NET) (compiled Jan 20 2011, 15: 58:25)

8. Clark R C and Reid J S 1995 Acta Cryst. A 51887

9. Altomare A, Burla M C, Camalli M, Cascarano G L, Giacovazzo C, Guagliardi A, Grazia A, Moliterni G, Polidori G and Spagna R 1999 J. App. Cryst. 32115

10. Betteridge P W, Carruthers J R, Cooper R I, Prout K and Watkin D J 2003 J. Appl. Cryst. 361487

11. Brandenburg K 1998 Diamond Version 2.0 Impact GbR. Bonn, Germany

12. Khedhiri L, Selmi A and Rzaigui M 2014 J. Chem. Biochem. 2179

13. Hamdi A, Khederi L and Rzaigui M 2014 Acta Cryst. E 70 o342

14. Salah R B H, Khederi L and Rzaigui M 2014 Acta Cryst. E 70 o61

15. Salah R B H, Khederi L, Ben Nasr C, Rzaigui M and Lefebre F 2010 Phosphorus, Sulfur Silicon Relat. Elem. 185595

16. Khedhiri L, Salah R B H, Belam W and Rzaigui M 2007 Acta Cryst. E 63 o2269
17. Khedhiri L, Ben Nasr C, Rzaigui M and Lefebre F 2003 Helv. Chim. Acta 862662

18. Averbuch-Pouchot M T and Durif A 1991 Eur. J. Solid State Inorg. Chem. 289

19. Averbuch-Pouchot M T and Schülke U 1995 Z. Kristallogr. 210129

20. Kapoor I P S, Kapoor M, Singh G and Frohlich R 2010 Indian J. Eng. Mater. Sci. 17305

21. Cui L-J and Xu H-J 2009 Acta Cryst. E 65 o2376

22. Long S, Siegler M and Li T 2007 Acta Cryst. E 63 o3080

23. Clegg W and Watson D G 2007 Acta Cryst. E 63 o929

24. Ben Nasr C and Rzaigui M 1999 Mater. Res. Bull. 34 557

25. Soudani S, Mi J-X, Lefebvre F, Jelsch C and Ben Nasr C 2015 J. Mol. Struct. 108446

26. Kamel K, Rayes A, Nasr C Ben, Rzaigui M and Lefebvre F 2003 Mater. Res. Bull. 38741

27. Oueslati A, Ben Nasr C, Durif A and Lefebvre F 2005 Mater. Res. Bull. 40970

28. Ben Nasr C 2000 Solid State Sci. 2501

29. Ben Nasr C, Saïd I and Rzaigui M 2001 Mater. Res. Bull. 36789

30. Silverstein R M, Bassler G C and Morill T C 1974 In Spectrometric Identification of Organic Compounds $3^{\text {rd }}$ ed. (New York: John Wiley) p. 76 